\title{
Antimicrobial activity of yeasts against some pathogenic bacteria
}

\author{
Gamal Younis ${ }^{1}$, Amal Awad ${ }^{1}$, Rehab E. Dawod ${ }^{2}$ and Nehal E. Yousef ${ }^{2}$
}

1. Department of Bacteriology, Mycology and Immunology, Faculty of Veterinary Medicine, Mansoura University, 35516 Mansoura, Egypt; 2. Department of Bacteriology, Animal Health Research Institute, Damietta Branch, Damietta, Egypt.

Corresponding author: Amal Awad, e-mail: amalabdo@mans.edu.eg

Co-authors: GY: gamalyounis_1@hotmail.com,RED: re7ab_re@yahoo.com, NEY: ezzatnehal1@gmail.com

Received: 16-03-2017, Accepted: 27-07-2017, Published online: 24-08-2017

doi: 10.14202/vetworld.2017.979-983 How to cite this article: Younis G, Awad A, Dawod RE, Yousef NE (2017) Antimicrobial activity of yeasts against some pathogenic bacteria, Veterinary World, 10(8): 979-983.

\begin{abstract}
Aim: This study was designed to isolate and identify yeast species from milk and meat products, and to test their antimicrobial activity against some bacterial species.

Materials and Methods: A total of 160 milk and meat products samples were collected from random sellers and super markets in New Damietta city, Damietta, Egypt. Samples were subjected to yeast isolation procedures and tested for its antimicrobial activity against Staphylococcus aureus, Pseudomonas aeruginosa, and Escherichia coli. In addition, all yeast species isolates were subjected to polymerase chain reaction (PCR) for detection of khs (kievitone hydratase) and pelA (pectate degrading enzyme) genes.
\end{abstract}

Results: The recovery rate of yeasts from sausage was $20 \%(2 / 10)$ followed by kareish cheese, processed cheese, and butter 10\% (1/10) each as well as raw milk 9\% (9/100), and fruit yoghurt 30\% (6/20). Different yeast species were recovered, namely, Candida kefyr (5 isolates), Saccharomyces cerevisiae (4 isolates), Candida intermedia (3 isolates), Candida tropicalis (2 isolates), Candida lusitaniae (2 isolates), and Candida krusei (1 isolate). khs gene was detected in all $S$. cerevisiae isolates, however, pelA gene was not detected in all identified yeast species. Antimicrobial activity of recovered yeasts against the selected bacterial species showed high activity with $C$. intermedia against $S$. aureus and $E$. coli, $C$. kefyr against $E$. coli, and $C$. lusitaniae against $S$. aureus. Moderate activities were obtained with $C$. tropicalis, $C$. lusitaniae, and $S$. cerevisiae against $E$. coli; meanwhile, all the tested yeasts revealed a very low antimicrobial activity against $P$. aeruginosa.

Conclusion: The obtained results confirmed that some kinds of yeasts have the ability to produce antimicrobial compounds that could inhibit some pathogenic and spoilage bacteria and these antimicrobial activity of yeasts enables them to be one of the novel agents in controlling spoilage of food.

Keywords: antimicrobial, meat products, milk, pathogenic bacteria, yeasts.

\section{Introduction}

Yeasts are one of the microorganisms found in milk and meat products. They are found in raw materials and in processed milk and meat products such as sausage, fruit yoghurt, and cheeses. Yeasts have the ability to produce antimicrobial compounds that could inhibit growth of harmful mold or bacteria [1]. In past two decades, there are few researchs conducted to investigate the role of naturally occurring yeasts for inhibiting the growth of foodborne bacteria with various mechanisms [2]. Chemical food preservatives are used commonly extending the shelf life and improving the safety of food by inhibiting the growth of pathogenic and spoilage bacteria. However, increasing fears of consumers about their toxicity and antimicrobial resistant pathogens that found in food, which constitute a direct risk to public health and this leads to searching for alternative methods of food preservation

Copyright: Younis, et al. Open Access. This article is distributed under the terms of the Creative Commons Attribution 4.0 International License (http://creativecommons.org/licenses/by/4.0/), which permits unrestricted use, distribution, and reproduction in any medium, provided you give appropriate credit to the original author(s) and the source, provide a link to the Creative Commons license, and indicate if changes were made. The Creative Commons Public Domain Dedication waiver (http://creativecommons.org/ publicdomain/zero/1.0/) applies to the data made available in this article, unless otherwise stated. as biopreservation [3]. Biopreservation means the use of natural or controlled microorganisms, or their antimicrobial compounds, to prolong the shelf life of food and to improve the safety of food. The suitability of yeast biocontrol agents and their strategies to enhance stress tolerance are important to their efficacy and commercial application [4].

Some kinds of yeasts secrete toxins and these types called killer yeasts. These yeasts can inhibit growth of other yeast strains and also, have antimicrobial activities inhibiting growth of mold and bacteria [1]. Killer yeasts are found naturally in rotten vegetables and fruits and have inhibitrory effects on the growth of other microorganisms. In addition, the yeasts which showed killer activity during beer and wine production and preservation of food are able to combat harmful microorganisms [5].

Saccharomyces cerevisiae is one of the widely studied microorganisms, and it has been involved in many biotechnological processes due to its good fermentation capacity [6]. Furthermore, it has probiotic and health benefit that has been reported recently [7]. Inhibitory effects to $S$. cerevisiae killer strains were discovered in 1963 and related to secretion of some toxins from this time to now, $\mathrm{k} 1$ and $\mathrm{k} 28$ are most common toxins [8]. In addation to $S$. cerevisiae, production 
of killer toxins has been discussed among many species of yeasts including Candida, Cryptococcus, Kluyveromyces, Debaromyces, Pichia, Williopsis, and Zygosaccharomyces $[9,10]$.

The main objectives of this study was to isolate and identify different species of yeasts from milk and meat products, and testing their inhibitory effects against some pathogenic bacterial species as well as detection of $k h s$ and pelA genes in the isolated yeast strains using PCR assay.

\section{Materials and Methods}

\section{Ethical approval}

There was no need of ethical approval in this study because no live animals were involved. Milk and meat product samples were collected as per standard sampling methods.

\section{Samples collection}

A total of 160 samples including, 100 samples from raw milk, 50 samples from milk products including, fruit yoghurt (20), kareish cheese (10), processed cheese (10) and butter (10), and 10 processed meat products samples (sausage) were subjected to yeast isolation procedures. All samples were collected from random sellers and super markets located at New Damietta city, Damietta, Egypt. Samples were collected aseptically in sterile bags separately and were transmitted directly to laboratory.

\section{Preparation of samples and isolation of yeasts}

One gram from each sample was inoculated in Glucose Yeast Extract Broth (GYEB) and incubated at $27^{\circ} \mathrm{C}$ for $24 \mathrm{~h}$. A loopful from the previous inoculated broth was subcultured onto Sabouraud dextrose agar (Oxoid) plates and incubated for $48 \mathrm{~h}$ at $37^{\circ} \mathrm{C}$ [11]. Separate colony from each of suspected yeasts was picked up and streaked onto SDA plate, incubated at $27^{\circ} \mathrm{C}$ for $48 \mathrm{~h}$ to get a pure culture and stored at $4^{\circ} \mathrm{C}$ for further examination.

\section{Identification of yeast isolates}

Yeasts were identified according to Wickerham and Burton [12] and Lodder and Kreger Van Rij [13] using traditional methods of identification including, growth on SDA plates, sugar fermentation, sugar assimilation, nitrate assimilation, ascospore formation, vegetative reproduction, and urea hydrolysis. Further identification of yeast isolates was done using VITEK 2 Compact method (BioMérieux, Marcy l’Étoile, France).

\section{Antimicrobial activity test}

Antimicrobial activity of yeast isolates against bacterial species was done according to Roostita et al. [14]. Briefly, yeast colony from each isolated species was sub cultured into $15 \mathrm{ml}$ GYEB and was incubated at $27^{\circ} \mathrm{C}$ for $48 \mathrm{~h}$. From the incubated broth, a loopful was cultivated aseptically onto SDA plate, then, the inoculated plates were incubated at $37^{\circ} \mathrm{C}$ for $48 \mathrm{~h}$. One isolate from each of $S$. aureus, E. coli, and $P$. aeruginosa (Department of Bacteriology, Mycology and Immunology, Faculty of Veterinary Medicine, Mansoura University, Egypt) was cultivated into $15 \mathrm{ml}$ nutrient broth and was incubated at $37^{\circ} \mathrm{C}$ for $24 \mathrm{~h}$, then, they were swept separately onto nutrient agar (NA) plates using sterile swabs. From the previously prepared yeast agar plates, few yeast colonies were carefully picked up using platinum loop and placed in the center of inoculated NA plates with $S$. aureus, E. coli and $P$. aeruginosa. Inoculated plates were incubated at $37^{\circ} \mathrm{C}$ for $24 \mathrm{~h}$, then, clear inhibition zones were measured using ruler.

\section{Molecular detection of $\boldsymbol{k h s}$ and pelA genes}

Yeast isolates were subjected to PCR for detection of $k h s$ and pelA genes according to Suga et al. [15]. Yeast DNA was extracted using QIAamp DNeasy Plant Mini kit Catalogue No. 69104 (Qiagen, Germany). The primer pairs used (sequence, target gene, and PCR product) are listed in Table-1. PCR was performed in a total volume of $25 \mu \mathrm{L}$ consisting of $12.5 \mu \mathrm{L}$ of $2 \mathrm{X}$ PCR Master Mix (Emeraldamp GT PCR master mix [Takara, Japan] Code No. RR310A), $1 \mu \mathrm{L}$ of each primer, and $6 \mu \mathrm{L}$ DNA templates and the volume of the reaction mixture was completed to $25 \mu \mathrm{L}$ using nuclease free water. PCR program for both

Table-1: Oligonucleotide primers sequences.

\begin{tabular}{llcc}
\hline Gene & Sequence & Amplified product & Reference \\
\hline khs & AAGCATCCGAAACAGTACT & $919 \mathrm{bp}$ & Suga et al., [33] \\
pelA & TCAAGGATGCTGCTAAGCTG & $727 \mathrm{bp}$ & \\
& ATCGAATTCATGAAGTTCACTGCTGCTTTC & & \\
\hline
\end{tabular}

khs: Kievitone hydratase gene

Table-2: Cycling conditions of the different primers during PCR.

\begin{tabular}{lcccccc}
\hline Target gene & $\begin{array}{c}\text { Primary } \\
\text { denaturation }\end{array}$ & No. of cycles & $\begin{array}{c}\text { Secondary } \\
\text { denaturation }\end{array}$ & Annealing temperature & Extension & Final extension \\
\hline$k h s$ & $95^{\circ} \mathrm{C}$ & 35 & $94^{\circ} \mathrm{C}$ & $53^{\circ} \mathrm{C}$ & $72^{\circ} \mathrm{C}$ & $72^{\circ} \mathrm{C}$ \\
\multirow{2}{*}{ pelA } & $5 \mathrm{~min}$ & & $30 \mathrm{~S}$ & $50 \mathrm{~s}$ & $50 \mathrm{~s}$ & $10 \mathrm{~min}$ \\
& $95^{\circ} \mathrm{C}$ & 35 & $94^{\circ} \mathrm{C}$ & $55^{\circ} \mathrm{C}$ & $72^{\circ} \mathrm{C}$ & $72^{\circ} \mathrm{C}$ \\
\hline
\end{tabular}

$\mathrm{PCR}=$ Polymerase chain reaction, $k h s=$ Kievitone hydratase gene 
$k h s$ and pelA genes was summarized in Table-2. The amplicons were analyzed by electrophoresis in $1.5 \%$ agarose gels (AB gene, USA) stained with ethidium bromide (Sigma, Germany) then photographed using a gel documentation system [16].

\section{Results and Discussion}

Milk acts as a good nutritional medium for yeasts growth; yeasts can ferment lactose, metabolize lactase, and produce carbonyl compounds, and volatile acids [17]. In the processed meat products, yeasts are objectionable, and they grow at a wide range of temperature and $\mathrm{PH}$ values, resulted in the spoilage of meat products. Their percent are used as an index of storage and hygienic safety of the product [18].

In this study, yeasts were isolated from $20 \%$ of examined sausage, $10 \%$ of kareish cheese, $10 \%$ of processed cheese, $10 \%$ of butter, $9 \%$ of raw milk, and $30 \%$ of fruit yoghurt (Table-3). These findings are lower than the findings of Ibrahim et al., [19] who found that the occurrence of yeast species in the examined kareish cheese, Damietta processed cheese, and yoghurt samples were $100 \%, 100 \%$, and $50 \%$, respectively. In this study, the high prevalence rate of yeasts in fruit yogurt might attributed to that the yoghurt offer a good condition for yeasts growth [20]. In addition, fruits increase percentage of yeasts by about 3.3-3.4 times [21].

In the current study, many kinds of yeasts associated with milk and meat products were identified including, C. krusei, C.kefyr (Kluyveromyces marxianus), C. tropicalis, C. intermedia, S. cerevisiae from raw milk samples, $C$. intermedia, $C$. lusitaniae and $C$. tropicalis from fruit yoghurt, $C$. lusitaniae from kareish cheese, C. kefyr (K. marxianus) from butter

Table-3: Incidence of yeasts in raw milk, milk products, and sausage.

\begin{tabular}{lcc}
\hline Type of sample & $\begin{array}{c}\text { Number of } \\
\text { examined } \\
\text { samples (160) }\end{array}$ & \begin{tabular}{c} 
Positive samples \\
\cline { 2 - 3 } Number (\%)
\end{tabular} \\
\hline Raw milk & 100 & $9(9)$ \\
Fruit yoghurt & 20 & $6(30)$ \\
Kareish cheese & 10 & $1(10)$ \\
Processed cheese & 10 & $1(10)$ \\
Butter & 10 & $1(10)$ \\
Sausage & 10 & $2(20)$ \\
\hline
\end{tabular}

and finally from sausage, C. kefyr (K. marxianus), and $S$. cerevisiae were recovered (Table-4). These findings are similar to the findings of many investigators [22-24] who identified nearly similar yeast species from milk and milk products.

In this study, some yeast isolates showed variable antimicrobial activities against $S$. aureus, E. coli, and $P$. aeruginosa. $C$. intermedia showed high antimicrobial activity against $E$. coli $(20 \mathrm{~mm})$ and $S$. aureus $(24 \mathrm{~mm})$ with large clear inhibition zone and low antimicrobial activity against $P$. aeruginosa $(6 \mathrm{~mm})$. C. kefyr showed high antimicrobial activity against E. coli $(20 \mathrm{~mm})$, low antimicrobial activity against $S$. aureus $(8 \mathrm{~mm})$, and no activity against $P$. aeruginosa. C. tropicalis showed moderate antimicrobial activity against $E$. coli $(14 \mathrm{~mm})$ and negative antimicrobial activity against $S$. aureus as well as $P$. aeruginosa. C. lusitaniae showed high antimicrobial activity against $S$. aureus $(22 \mathrm{~mm})$, moderate antimicrobial activity against $E$. coli $(12 \mathrm{~mm})$ and negative result against $P$. aeruginosa. $S$. cerevisiae showed moderate antimicrobial activity against $E$. coli $(12 \mathrm{~mm})$, low antimicrobial activity against $S$. aureus $(8 \mathrm{~mm})$ and negative antimicrobial activity against $P$. aeruginosa $(5 \mathrm{~mm})$ as shown in Table-5. These findings confirming the previous results of Roostita et al. [14], Abd Elatif et al. [25] who tested yeast species isolates recovered from livestock products on some pathogenic bacteria such as $P$. aeruginosa, E. coli, and S. aureus. Furthermore, Rajkowska et al. [26] also found a decreasing in $S$. aureus cells number after incubation with probiotic yeasts. The antimicrobial activity of the isolated yeasts against the used bacterial species might be attributed to production of some yeast products such as, volatile thermolabile toxic extract [27]. Another yeast products such as antilisterial hydrophobic peptides and mycocins against bacterial pathogens were also recently investigated [28-30].

Among the isolated yeast species, $S$. cerevisiae is considered a one of the killer yeasts that has $k h s$ gene as a killer mechanism [31]. In this study, khs gene was identified using PCR assay in $S$. cerevisiae which may be responsible for the bacterial growth inhibition on the inoculated plates (Figure-1). $k h s$ gene was previously identified in Fusarium phaseoli [15] and in Nectria haematococca [32]. In this study, pelA

Table-4: Different types of recovered yeasts from examined samples.

\begin{tabular}{|c|c|c|c|c|c|c|c|}
\hline \multirow[t]{2}{*}{ Type of yeast } & \multirow[t]{2}{*}{ Raw milk } & \multirow[t]{2}{*}{ Fruit yoghurt } & \multirow[t]{2}{*}{ Kareish cheese } & \multirow{2}{*}{$\begin{array}{c}\text { Processed } \\
\text { cheese }\end{array}$} & \multirow[t]{2}{*}{ Butter } & \multirow[t]{2}{*}{ Sausage } & \multirow{2}{*}{$\frac{\text { Total }}{\text { Number }(\%)}$} \\
\hline & & & & & & & \\
\hline C. kefyr (K. marxianus) & 3 & - & - & 1 & 1 & - & $5(25)$ \\
\hline C. krusei & 1 & - & - & - & - & - & $1(5)$ \\
\hline C. tropicalis & 1 & 1 & - & - & - & - & $2(10)$ \\
\hline C. Iusitaniae & - & 1 & 1 & - & - & - & $2(10)$ \\
\hline C. intermedia & 2 & 1 & - & - & - & - & $3(15)$ \\
\hline S. cerevisiae & 2 & - & - & - & - & 2 & $4(20)$ \\
\hline Unidentified yeasts & - & 3 & - & - & - & - & $3(15)$ \\
\hline
\end{tabular}

C. kefyr=Candida kefyr, K. marxianus=Kluyveromyces marxianus, C. krusei=Candida krusei, C. tropicalis=Candida tropicalis, C. Iusitaniae=Candida lusitaniae, C. intermedia=Candida intermedia, S. cerevisiae=Saccharomyces cerevisiae 
Table-5: Antimicrobial activity of recovered yeasts against $E$. coli, S. aureus, and $P$. aeruginosa.

\begin{tabular}{|c|c|c|c|c|c|c|}
\hline \multirow[t]{2}{*}{ Yeast type } & \multicolumn{2}{|c|}{ E. coli } & \multicolumn{2}{|c|}{ S. aureus } & \multicolumn{2}{|c|}{ P. aeruginosa } \\
\hline & DIZ & Result & DIZ & Result & DIZ & Result \\
\hline C. intermedia & 20 & +++ & 24 & ++++ & 6 & + \\
\hline $\begin{array}{l}\text { C. kefyr } \\
\text { (K. marxianus) }\end{array}$ & 20 & +++ & 8 & + & - & - \\
\hline C. tropicalis & 14 & ++ & - & - & - & - \\
\hline C. Iusitaniae & 12 & ++ & 22 & ++++ & - & - \\
\hline C. krusei & - & - & - & - & - & - \\
\hline S. cerevisiae & 12 & ++ & 8 & + & 5 & - \\
\hline
\end{tabular}

E. coli=Escherichia coli, S. aureus=Staphylococcus aureus,

$P$. aeruginosa $=P$ seudomonas aeruginosa, DIZ=Diameter of inhibition zone by $\mathrm{mm}$ without zone of yeast growth. - (negative): 0-5 mm, + (low): 6-10 mm, ++ (moderate): 11-15 mm, +++ (high): 16-20 mm, ++++ (very high): $21-25 \mathrm{~mm}$

Table-6: Results of PCR for detection of khs andpelA genes in different yeast isolates.

\begin{tabular}{llcc}
\hline $\begin{array}{l}\text { Samples } \\
\text { types }\end{array}$ & Isolates & khs gene pelA gene \\
\hline Raw milk & S. cerevisiae & + & - \\
Raw milk & C. tropicalis & - & - \\
Raw milk & C. intermedia & - & - \\
Raw milk & C. intermedia & - & - \\
Raw milk & S. cerevisiae & + & - \\
Raw milk & C. kefyr & - & - \\
Raw milk & C. kefyr & - & - \\
Raw milk & C. kefyr & - & - \\
Raw milk & C. krusei & - & - \\
Fruit yoghurt & Unidentified yeasts & - & + \\
Fruit yoghurt & Unidentified yeasts & - & + \\
Fruit yoghurt & C. intermedia & - & - \\
Fruit yoghurt & C. lusitaniae & - & - \\
Fruit yoghurt & Unidentified yeasts & - & + \\
Fruit yoghurt & C. tropicalis & - & - \\
Sausage & S. cerevisiae & + & - \\
Sausage & S. cerevisiae & + & - \\
Kareish cheese & C. lusitaniae & - & - \\
Butter & C. kefyr & - & - \\
Processed & C. kefyr & - & - \\
cheese & & & \\
\hline
\end{tabular}

C. kefyr=Candida kefyr, C. krusei=Candida krusei, C. tropicalis=Candida tropicalis, C. Iusitaniae=Candida lusitaniae, C. intermedia=Candida intermedia,

S. cerevisiae $=$ Saccharomyces cerevisiae, $K h s=$ Kievitone hydratase gene, $\mathrm{PCR}=$ Polymerase chain reaction

Table-7: Cumulative results of PCR for detection of khs and $p e l A$ genes in different strains.

\begin{tabular}{lccc}
\hline Yeast strain & $\begin{array}{c}\text { Number } \\
\text { of isolates }\end{array}$ & Khs gene & PelA gene \\
\hline S. cerevisiae & 4 & + & - \\
C. kefyr & 5 & - & - \\
C. intermedia & 3 & - & - \\
C. Iusitaniae & 2 & - & - \\
C. tropicalis & 2 & - & - \\
C. krusei & 1 & - & - \\
Unidentified yeasts & 3 & - & + \\
\hline
\end{tabular}

C. kefyr=Candida kefyr, C. krusei=Candida krusei,

C. tropicalis=Candida tropicalis, C. Iusitaniae $=$ Candida Iusitaniae, C. intermedia=Candida intermedia,

S. cerevisiae $=$ Saccharomyces cerevisiae, $\mathrm{PCR}=$ Polymerase chain reaction, $k h s=$ Kievitone hydratase gene

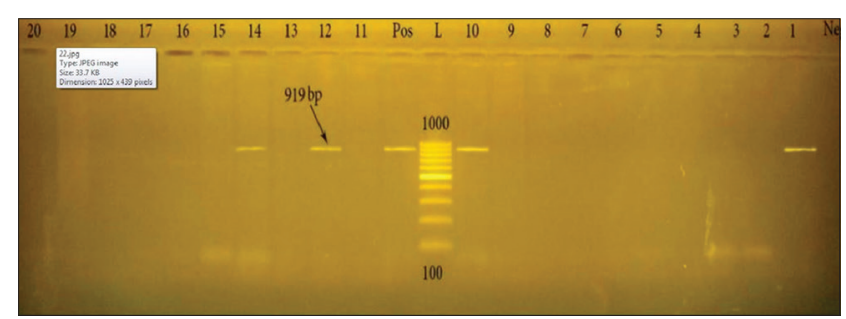

Figure-1: Agarose gel electrophoresis of polymerase chain reaction products on different yeast species demonstrating khs gene at 919 bp. Pos: Positive control, L: 100 bp DNA ladder, Neg: Negative control.

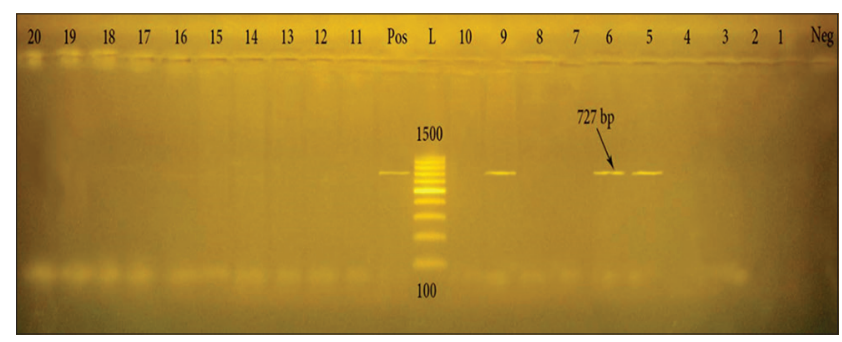

Figure-2: Agarose gel electrophoresis of polymerase chain reaction products on different yeast species demonstrating pelA gene at 727 bp. Pos: Positive control, L: 100 bp DNA ladder, Neg: Negative control.

gene (pectate degrading enzyme) could not be identified in all identified yeast species (Tables 6 and 7), but it could be identified in three unidentified yeast species (Figure-2), pelA gene found in other fungal species including Fusarium solani spp. Pisi (MP VI), xanthoxyli (MP IV), batatas (MP II), and mori (MP III) [33,34].

\section{Conclusion}

In this study, different kinds of yeasts had the ability to produce antimicrobial compounds that could inhibit the growth of the selected pathogenic bacterial species. khs gene which responsible for the killer mechanism in $S$. cerevisiae had been successfully identified in all recovered $S$. cerevisiae isolates.

\section{Authors' Contributions}

GY planned and design the study, shared in data analysis and revised the manuscript, NEY and AA performed the tests, wrote the manuscript, and analyzed the data. RED shared in performance of tests and wrote a part of manuscript. All authors read and approved the final manuscript.

\section{Acknowledgments}

The authors would like to thank all the members at the Department of Bacteriology, Mycology and Immunology, Faculty of Veterinary Medicine, Mansoura University, for their technical help. The authors declare that they did not have any funding source to support their study.

\section{Competing Interests}

The authors declare that they have no competing interests. 


\section{References}

1. Li, Q., Huang, J., Guo, H., Guo, X., Zhu, Y. and Dong, K. (2012) Bactericidal activity against meticillin-resistant Staphylococcus aureus of a novel eukaryotic therapeutic recombinant antimicrobial peptide. Int. J. Antimicrob. Agents, 39: 496-499.

2. Liu, J., Sui, Y., Wisniewski, M., Droby, S. and Liu, Y. (2013) Review: Utilization of antagonistic yeasts to manage postharvest fungal diseases of fruit. Int. J. Food Microbiol., 167: 153-160.

3. Carocho, M., Morales, P. and Ferreira, I.C.F. (2015) Natural food additives: Quo vadis? Trends Food Sci. Technol., 45: 284-295.

4. Sui, Y., Wisniewski, M., Droby, S. and Liu, J. (2015) Responses of yeast biocontrol agents to environmental stress. Appl. Environ. Microbiol., 81: 2968-2975.

5. Lim, S.L. and Tay, S.T. (2011) Diversity and killer activity of yeasts in Malaysian fermented food samples. Trop. Biomed., 28(2): 438-443.

6. Fakruddin, M.D., Hossain, M.D.N. and Ahmed, M.M. (2017) Antimicrobial and antioxidant activities of Saccharomyces cerevisae LFSTO62013, a potential probiotic. BMC Complement. Altern. Med., 17: 64.

7. Fijan, S. (2014) Microorganisms with claimed probiotic properties: An overview of recent literature. Int. J. Environ. Res. Public Health, 11: 4745-4767.

8. Breinig, F., Sendzik, T., Eisfeld, K. and Schmitt, M.J. (2006) Dissecting toxin immunity in virus-infected killer yeast uncovers an intrinsic strategy of self-protection. Proc. Natl. Acad. Sci. USA, 103(10): 3810-3815.

9. Young, T.W. (2012) Killer yeasts. In: Rose, A.H., Harrison, J.S., editors. The Yeasts. $2^{\text {nd }}$ ed. Academic Press, London, UK. p131-164.

10. Muccilli, S., Wemhoff, S., Restuccia, C. and Meinhardt, F. (2013) Exoglucanase-encoding genes from three Wickerhamomyces anomalus killer strains isolated from olive brine. Yeast, 30: 33-43.

11. Roostita, R. (1993) Occurrence, Growth and Biochemical Properties of Yeasts in Cheeses and Milk. A Thesis, the University of New South Wales, Australia.

12. Wickerham, L.J. and Burton, K.A. (1948) Carbon assimilation test for the classification of yeasts. J. Bacteriol., 56: 363-371.

13. Lodder, J. and Kreger-van Rij, N.J.W. (1970) The Yeasts, a Taxonomic Study. North Holland Publ. Co., Amsterdam.

14. Roostita, L.B., Fleet, G.H., Wendry, S.P., Apon, Z.M. and Gemilang, L.U. (2011) Determination of yeasts antimicrobial activity in milk and meat products. Adv. J. Food Sci. Technol., 3(6): 442-445.

15. Suga, H., Ikeda, S., Taga, M., Kageyama, K. and Hyakumachi, M. (2002) Electrophoretic karyotyping and gene mapping of seven Formae speciales in Fusarium solani. Curr. Genet., 41(4): 254-260.

16. Sambrook, J., Fritscgh, E.F. and Mentiates, T. (1989) Molecular Coloning: A Laboratory Manual. $2^{\text {nd }}$ ed. Cold Spring Harbor Laboratory, New York.

17. Fleet, G.H. (1992) Food spoilage yeasts. In: Spencer, J.F.T. and Spencer, D.M., editors. Yeast Technology. SpringerVerlag, Berlin.

18. Ahmed, A.M. and Ismail, T.H. (2010) Improvement of the quality and shelf-life of minced-beef mixed with soyprotein by Sage (Salvia officinalis). Afr. J. Food Sci., 4(6): 330-334.

19. Ibrahim, J.I., Salama, E., Saad, A. and Helmy, A.A. (2015)
Microbial quality of some dairy products in Ismailia city. In: $2^{\text {nd }}$ Conference of Food Safety, Suez Canal University, Faculty of Veterinary Medicine. Vol. 1. p14-21.

20. Viljoen, B.C., Knox, A.M., Jager, P.H. and LourensHattingh, A. (2003) Development of yeast populations during processing and ripening of blue veined cheese. Food Technol. Biotechnol., 41: 291-297.

21. Šalomskiene, J. and Macioniene, I. (2009) The influence of contamination yoghurt, quark and semi-hard cheese by yeasts on their sensory properties. Vet. Med. Zootec., 48(70): 72-76.

22. El-Sharoud, W.M., Belloch, C., Peris, D. and Querol, A. (2009) Molecular identification of yeasts associated with traditional Egyptian dairy products. J. Food Sci., 74: 341-346.

23. Seker, E. (2010) Identification of Candida species isolated from bovine mastitic milk and their in vitro haemolytic activity in western turkey. Mycopathologia, 169: 303-308.

24. Wanderley, L., Bianchin, A., Arruda Teo, C.R.P. and Meneghello, F.A. (2013) Occurrence and pathogenicity of Candida spp. in unpasteurized cheese. Braz. J. Biosci., 11: 145-148.

25. Abdelatif, S.S., Elsayed, S.M., Bahout, A.A. and Bayoumi, A.M. (2016) Studies on beneficial yeasts isolated from some Egyptian dairy products. Zagazig Vet. J., 44(1): 75-84.

26. Rajkowska, K., Bska, A.K. and Rygal'a, A. (2012) Probiotic activity of Saccharomyces cerevisiae var. Boulardii against human pathogens. Food Technol. Biotechnol., 50(2): 230-236.

27. Viljoen, B. (2006) Yeast ecological interactions. Yeastyeast, yeast-bacteria, yeast-fungi interactions and yeasts as biocontrol agents. In: Querol, A. and Fleet, G., editors. The Yeasts Handbook: Yeasts in Food and Beverages. SpringerVerlag, Berlin, Germany. p83-110.

28. Hatoum, R., Labrie, S. and Fliss, I. (2013) Identification and partial characterization of anti listerial compounds produced by dairy yeasts. Probiotics Antimicrob. Proteins, 5: 8-17.

29. Chen, Y., Aorigele, C., Wang, C., Simujide, H. and Yang, S. (2015) Screening and extracting mycocin secreted by yeast isolated from koumiss and their antibacterial effect. J. Food Nutr. Res., 3:52-56.

30. França, R.C., Conceição, F.R., Mendonça, M., Haubert, L., Sabadin, G., de Oliveira, P.D., Amaral, M.G., Silva, W.P. and Moreira, Â.N. (2015) Pichia pastoris X-33 has probiotic properties with remarkable antibacterial activity against Salmonella Typhimurium. Appl. Microbiol. Biotechnol., 99: 7953-7961.

31. Fukuda, K., Kichise, H., Kitano, K. and Hara, S. (1991) Cloning and nucleotide sequence of the KHS killer gene of Saccharomyces cerevisiae. Agric. Biol. Chem., 55(8): 1953-1958.

32. Li, D., Chung, K.R., Smith, D.A. and Schardl, C.L. (1995) The Fusarium solani gene encoding kievitone hydratase, a secreted enzyme that catalyzes detoxification of a bean phytoalexin. Mol. Plant Microbe Interact, 8: 388-397.

33. Suga, H., Hasegawa, T., Mitsui, H., Kageyama, K. and Hyakumachi, M. (2000) Phylogenetic analysis of the phytopathogenic fungus Fusarium solani based on the rDNA-ITS region. Mycol. Res., 104: 1175-1183.

34. O'Donnell, K. (2000) Molecular phylogeny of the Nectria haematococca-Fusarium solani species complex. Mycologia, 92: 919-938. 